\title{
Analysis of Feasibility Teaching Material on Molecular Shape Topic Based on Criteria Board of National Education Standards in Indonesia
}

\author{
Anggi Desviana Siregar \\ Program of Postgraduate, \\ Universitas Negeri Medan \\ Medan, Indonesia \\ email : adesviana27@gmail.com
}

\author{
Muhammad Yusuf \\ Program of Postgraduate, \\ Universitas Negeri Medan \\ Medan, Indonesia
}

\author{
Ramlan Silaban \\ Program of Postgraduate, \\ Universitas Negeri Medan \\ Medan, Indonesia
}

\begin{abstract}
Teaching materials is one of the learning tools that become an important factor in influencing the success of learning, especially in college. So to improve the quality of learning needs to be done to improve the quality of learning tools, in order to facilitate students in understanding the material including chemistry learning materials. This study aims to analyze the instructional materials in the form of a book used in the basic concepts of chemistry precisely the material of molecular form. Research method using Research and Development with stages of Analysis, Design, Development, Implementation and Evaluation (ADDIE). The research instrument is a questionnaire of feasibility of teaching materials Based on Criteria Board of National Education Standards in Indonesia. The feasibility of molecular material material materials was analyzed based on content feasibility data, language feasibility, feasibility of presentation and feasibility of arragement. The result of learning $A$ teaching material as a whole is feasible and teaching materials $B$ is feasible but still needs to be revised and developed. The results obtained are early descriptions of basic chemistry books analyzed for further development into products of innovative chemistry materials based on KKNI curriculum.
\end{abstract}

Keywords : teaching material, molecular shape, criteria board of national education standards

\section{INTRODUCTION}

The Government of Indonesia has made a lot of efforts in order to improve the quality of education, one of which is the renewal of curriculum in educational institutions, including curriculum in universities. Medan State University (UNIMED) is one of the universities that implement KKNI-based curriculum since lecture year 2016/2017. One of the compulsory subjects in the curriculum structure of education program at FMIPA UNIMED is the basic chemistry concept lesson 2 credits. The basic chemistry concept course contains basic chemistry that delivers more complex and profound chemistry. Wasonowati (2014) states that chemistry is a product of natural knowledge in the form of facts, theories, principles, and laws of scientific work processes. Thus, in the implementation of learning should include three main aspects of products, processes, and scientific attitudes. However, learners often have difficulty understanding chemicals because they are abstract and have complex concepts. These difficulties lead to low understanding of the concepts of learners about various chemicals.

Molecular form is one of the elusive chemistry of students. Characteristic molecular form material is a three-dimensional form of molecule determined by the number of bonds and the magnitude of bond angles around the central atom (Effendi, 2008). Molecular form materials are generally abstract concepts that require rote and skills to understand the material. This is in line with the results of research conducted Habiba (2008) found as many as $56.1 \%$ of students who still have difficulty in describing the form of molecules. He asserted that the possibility of such errors is because students have experienced errors in previous stages because students do not understand the basic principles of electron domain theory. Another study conducted by Mustofa (2013) found that as many as $49.9 \%$ of students class XI SMA Negeri 1 Gorontalo can not describe the form of molecules because they do not understand the material form molecules.

One of the efforts to streamline the learning process and facilitate the delivery of material to learners can be done with the use of teaching materials in the form of books or learning modules. The existing textbooks emphasize more on the content dimension than the process and context dimensions required by PISA (Word 2007), so the important problem often faced by educators in learning activities is choosing or 
determining the right materials in order help students achieve competence. This is due to the fact that the lack of quality chemistry materials in the universities in accordance with the curriculum or syllabus. To be able to choose a good textbook, needed a way of book analysis involving aspects that contain science literacy that is content, process and context prepared in BSNP questionnaire

Based on the above description analysis is an activity that contains a number of activities such as parsing, differentiating, choosing something to be classified and regrouped according to certain criteria then searched for and interpreted meaning [16]. The analysis was conducted based on the questionnaire of feasibility level of the modified chemistry guide from the National Education Standards Agency / Badan Standar Nasional Pendidikan (BSNP) questionnaire which consisted of the feasibility of content, the feasibility of language, the feasibility of presentation and feasibility of graphic.

\section{RESEARCH METHOD}

This research is a research development. Research development is an attempt to develop an effective product for school use and not to test theory (Gay, 1990). Research and Development $(\mathrm{R} \& \mathrm{D})$ is a process used to develop and validate educational products. The steps of this process are usually referred to as the R \& D cycle, which consists of studying the research findings related to the product to be developed, developing the product based on these findings, the testing field in the setting where it will be used eventually and revising it to correct the deficiencies found in the testing phase (Borg \& Gall, 1983).

Analysis of basic chemistry textbooks of molecular form materials for basic chemistry 1st semester course majoring in FMIPA educational study program using Research and Development $(\mathrm{R} \& \mathrm{D})$ research design. This research design uses the ADDIE model (analysis, design, development, implementation, and evaluation). This research is only carried out in the early stages of development of materials of molecular material form. The types of data obtained in the analysis of this book are qualitative and quantitative data. Qualitative data are comments, suggestions or criticisms of the books analyzed. While quantitative data in the form of numbers obtained based on the validation sheet of study guide using Likert scale $(4,3,2,1)$. The data collection instrument used in this research is the validation sheets $\mathrm{A}, \mathrm{B}$, and $\mathrm{C}$ manuals based on BSNP standard. Data analysis techniques used to analyze data validation of the book is the technique of calculating the average. According to Arikunto [17], the range of validation criteria for complete calculation results can be observed in Table 1.

\section{RESEARCH RESULTS AND DISCUSSION}

The analysis is an activity that contains a number of activities such as parsing, differentiating, choosing something to be classified and regrouped according to certain criteria then searched for and interpreted meaning [16]. The analysis was conducted based on the questionnaire of feasibility level of the modified chemistry guide from the National Education Standards Agency/BadanStandarNasionalPendidikan (BSNP) questionnaire which consisted of the feasibility of content, the feasibility of language, the feasibility of presentation and feasibility of graphic.

Before undertaking the development of innovative teaching materials. Researchers conducted an analysis of the books circulating in the educational program majors FMIPA State University of Medan. The teaching materials that were analyzed amounted to 2 different teaching materials author and publisher initialized teaching materials $\mathrm{A}$ and $\mathrm{B}$. The standardization test based on the modified BSNP includes 4 aspects: (1) the feasibility of the content; (2) language feasibility; (3) feasibility of presentation; and (4) feasibility of kegrafikan. The data that is obtained is a description of the teaching materials with the qualification of the list of check list $(\sqrt{ })$ in column score 1 to 4 that is: (1) strongly disagree; (2) disagree; (3) agree; and (4) strongly agree.

The results of the analysis of teaching materials conducted by researchers on the materials $\mathrm{A}$ and $\mathrm{B}$ are shown in the figure 1 .

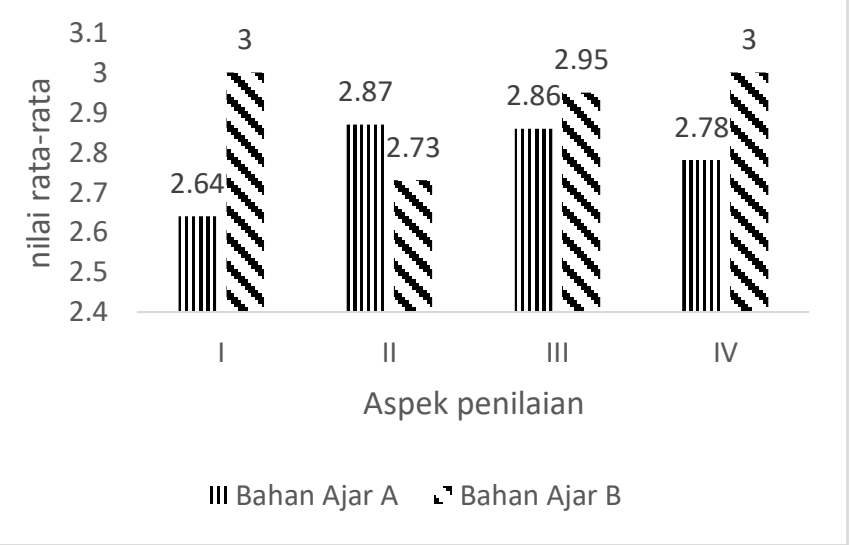

Fig1. Graph of analysis result of A and B materials based on BSNP

The results of the content feasibility analysis state that the study guide that has been analyzed is valid and usable. But there is still some that should be on the content feasibility of the depth of the material needs to be re-adjusted with teaching materials, sub-material conformity in practical guidance with the concept and addition of learning objectives in each practical. activity. Validation of content feasibility can be seen in figure 2 . 


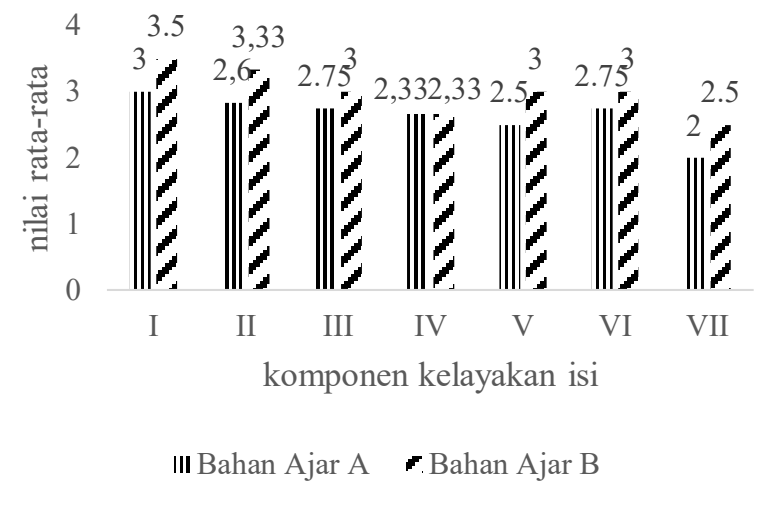

Fig 2. Graph of Feasibility Analysis Result of the Materials Content $\mathrm{A}$ and $\mathrm{B}$

The result of the language feasibility analysis states that the practicum manuals analyzed are valid and applicable. However, by adjusting the sentence that accompanies the picture or illustration to make it look more clear. Validation of language eligibility can be seen in figure 3 .

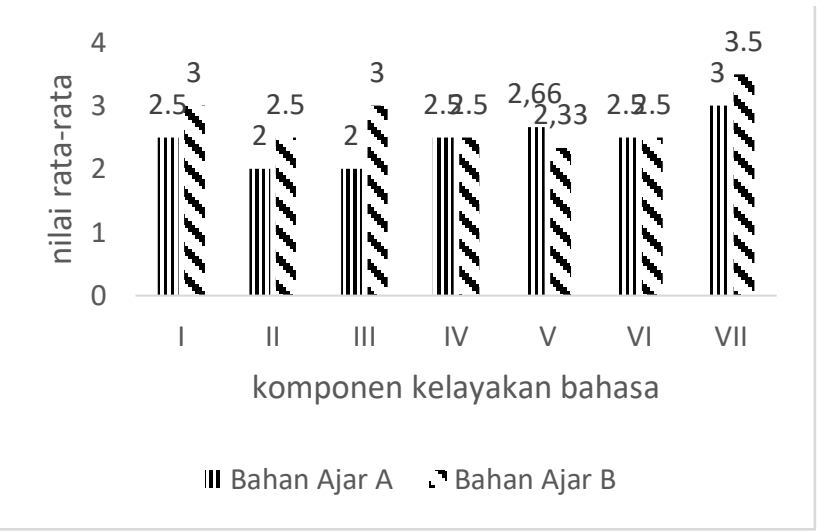

Fig 3. Graph of Feasibility Analysis Result of Language of teaching materials $\mathrm{A}$ and $\mathrm{B}$

The results of the analysis on the feasibility of the presentation stated that the study guide book that was analyzed was valid and could be used. However, by improving the cover design and the overall design of the practicum guide to attracting students' interest. Validation of presentation feasibility can be seen in figure 4 .

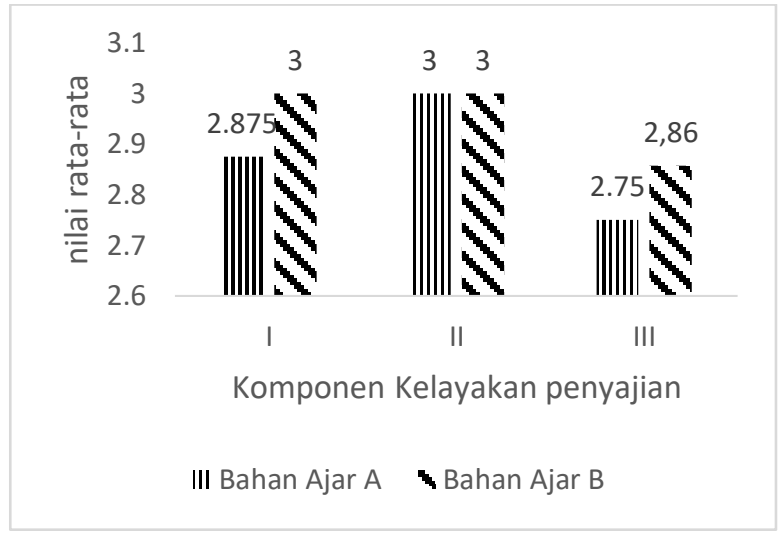

Fig 4. Graph of Feasibility Analysis Result of Presentation of $\mathrm{A}$ and $\mathrm{B}$ Materials

The results of the analysis on the feasibility of graphic stated that the study guide book that has been analyzed has been valid and can be used. However, by improving the size of the book to comply with ISO standards. Validation of the feasibility of graphics can be seen in figure 5 .

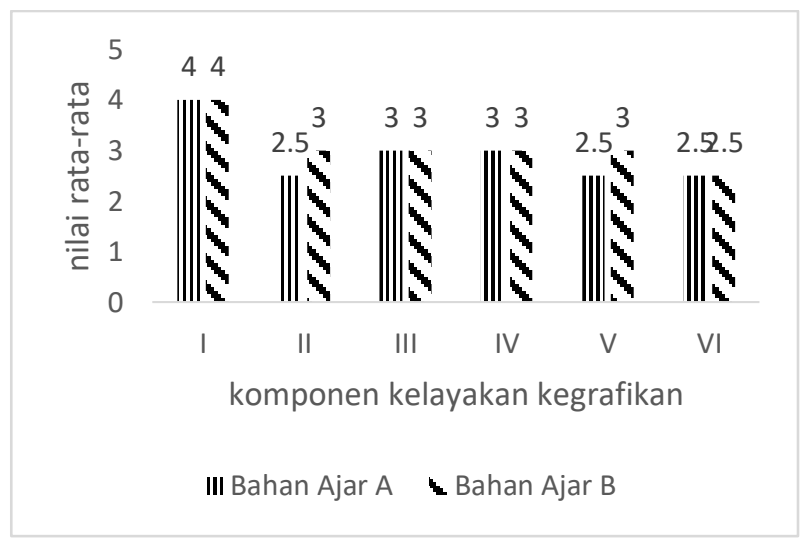

Fig 5. Graph of Result of Feasibility Analysis of Material A and $\mathrm{B}$

The result of chemistry textbook analysis at publisher A on chemistry subject matter based on BSNP that has been modified on the aspect of feasibility of aquality obtained an average value of 2.78 is valid, meaning it is feasible but needs revision. The result of chemistry textbook analysis at publisher $\mathrm{B}$ on chemistry subject matter based on BSNP which has been modified on the content feasibility aspect obtained an average value of 3.00 is valid, its meaning worthy and not need revision.

\section{CONCLUSION}

Based on the results of data analysis research The Learning material on molecular shape topic used in the basic chemistry concept courses are analyzed consisting of four parts: content 
feasibility, language feasibility, feasibility of presentation and graphic feasibility. Based on the above description, the book that has been analyzed is feasible to use but there are still some things that must be developed considering the book still have some shortcomings so that the need for development in accordance with the applicable university curriculum.

\section{REFERENCES}

[1] G. Sugiharti, and A. Muliaman, "Perbandingan Hasil Belajar Siswa yang Diajar Dengan Menggunakan Model Contextual Teaching And Learning dan Guided Inquiry pada Pokok Bahasan Struktur Atom," Jurnal Pendidikan Kimia, Vol. 8, pp. 5-11, April 2016.

[2] G. Raymond, Rendahnya kualitas pendidikan di Indonesia, 2017. [online 31 Oktober 2017], Accessed from: http://psychology.binus.ac.id.

[3] A. Muliaman, and L. M. Hutagaoul, "Improvement of Student Learning Outcome Using Model of Collaborative Based Lesson Study With Student,s Worksheet on Materials Hydrolys," Annual International Seminar on Transformative Education and Educational Leadership (AISTEEL), Vol. 2, pp. 141-145, Desember 2017.

[4] S. Alhadi, and W. N. E. Saputra, "The Relationship between Learning Motivation and Learning Outcome of Junior High School Students in Yogyakarta," Advances in Social Science Education and Humanities Research (ASSEHR), Vol. 66, pp. 138-141, 2017.

[5] E. Prayitno,Motivasi dalam Belajar, Jakarta: PPLPTK Depdikbud, 1989.

[6] S. Arikunto, Prosedur Penelitian, Jakarta: Rineka Cipta, 2013.

[7] M. Wena, Strategi Pembelajaran Inovatif Kontemporer, Jakarta: Bumi Aksara, 2011.

[8] S. Pape, C. Bell, and I. Yetkin, "Developing mathematical thinking and self-regulated learning: A teaching experiment in a seventh grade mathematics classroom," Education Study Matheamtics, vol. 53, pp. 179-202 ST-Developing mathematical thinking and, 2003.

[9] S. Patimah. Hubungan Motivasi Belajar dengan Hasil Belajar Siswa pada Mata Pelajaran Ilmu Pengetahuan Sosial Kelas IV SD Negeri 18/I Desa Teluk, 2014. [Online 6 October 2017], Accessed from: ecampus.fkip.unja.ac.id.

[10] R. Palupi, S. Anitah, and Budiyono, "Hubungan antara Motivasi Belajar dan Persepsi Siswa Terhadap Kinerja Guru Dalam Mengelola Kegiatan Belajar Dengan Hasil Belajar IPA Siswa Kelas Viii di SMPN N 1 Pacitan," Jurnal Teknologi Pendidikan dan Pembelajaran, vol. 2, no. 2 , pp. 157-170, 2014.

[11] J. A. Glover \& R. H. Bruning. Educational Psychology: Principles and Application. Columbus: Charles E. Merril Publishing Company, 1990.

[12] M. D. Gall, J. P. Gall, R. W. Borg. Educational Research: an Introduction. New York: Longman, 2003.

[13] N. Sudjana, Penilaian Hasil Proses Belajar Mengajar, Bandung: PT Remaja Rosdakarya, 2009.

[14] R. Trinora, R. Riswandi, \& E. Mustakim, "Hubungan Motivasi Belajar dan Hasil Belajar Siswa," Jurnal Pedagogi, vol 3, no. 1, 2015.

[15] O. A. Abuameerh and M. Al Saudi, "The Relationship between Achievement Motivation and Academic Achievement for Secondary School Students at Salt in Jordan," Dirasat: Educational Sciences, vol. 39, no. 1, pp. 313-320, 2012.

[16] A.-O. Emmanuel, E. A. Adom, B. Josephine, and F. K. Solomon, "Achievement Motivation, Academic Self-Concept and Academic Achievement Among High School Students," European Journal of Research and Reflection in Educational Sciences, vol. 2, no. 2, pp. 2437, 2014.

[17] J. M. Muola, "A study of the relationship between academic achievement motivation and home environment among standard eight pupils," Educational Research and Reviews, vol. 5, no. 4, pp. 213-217, 2010 . 